\title{
Abundance and distribution of juvenile white shrimp Litopenaeus setiferus within a tidal marsh landscape
}

\author{
Stacey R. Webb*, R. T. Kneib \\ University of Georgia Marine Institute, Sapelo Island, Georgia 31327, USA
}

\begin{abstract}
We measured variation in low-tide abundance of juvenile white shrimp Litopenaeus setiferus in subtidal creek channels relative to the amount of intertidal drainage area and creek edge in an adjacent tidal marsh. Samples were collected over a 2 yr period (1998 and 1999) and included 201384 individual shrimp taken by cast net during July to November from 4 different tidal creek subsystems in the Sapelo Island National Estuarine Research Reserve on the coast of Georgia (USA). Total drainage areas of the sub-systems ranged from 0.59 to $1.19 \mathrm{~km}^{2}$. Variation in intertidal and subtidal areas, and creek edge (interface between the vegetated marsh and open water) within the upper, middle and lower reaches of each sub-system was measured from high-resolution scaled (1:16 000) aerial photographs. Shrimp were most abundant and smaller in the upper reaches of tidal channels, where the adjacent intertidal drainage area and vegetated marsh edge were greatest. Regression analysis of shrimp abundance, measured as mean catch per unit effort, showed a strong positive relationship ( $<<0.001 ; \mathrm{R}^{2}=0.86$ ) with the amount of intertidal marsh edge in associated reaches (upper, middle or lower) of the creek sub-systems. Distribution and abundance of shrimp within tidal creeks probably reflected a link between estuarine landscape structure and accessibility of resources in the vegetated marshes that support shrimp production. Among the implications for management of shrimp resources in marsh habitats, we recommend a precautionary approach in making land-use decisions that would reduce structural complexity of marsh landscapes, particularly in the upper reaches of tidal creeks where juvenile white shrimp are concentrated and complex networks of creek channels enhance access to intertidal resources within the estuarine nursery.
\end{abstract}

KEY WORDS: Crustacean · Edge · Essential fish habitat · Estuarine nursery · Intertidal · Penaeid Shrimp · Sapelo Island

Resale or republication not permitted without written consent of the publisher

\section{INTRODUCTION}

Juvenile penaeid shrimp are among the most abundant of the marine transient species that rely on shallow waters of temperate and subtropical estuaries for a nursery habitat (Kutkuhn 1966, Weinstein 1979). In the southeastern US, 3 shrimp species support a substantial commercial fishery along the coast from North Carolina to Texas, with the value of the landings averaging \$471 million $\mathrm{yr}^{-1}$ during 1990 to

\footnotetext{
*Present address: Florida Department of Environmental Protection, 2600 Blair Stone Road, M.S. 3555, Tallahassee, Florida 32309, USA. E-mail: stacey.webb@dep.state.fl.us
}

1999 (National Marine Fisheries Service, Fisheries Statistics and Economic Division, Silver Spring, MD; available at: www.st.nmfs.gov). White shrimp Litopenaeus setiferus (formerly Penaeus setiferus, see Perez-Farfante \& Kensley 1997) represent about $40 \%$ of the total value of shrimp landings in the entire region, but over $85 \%$ of the penaeid harvest in the state of Georgia. Loss of high-quality juvenile nursery habitats is considered to be among the most serious potential threats to the white shrimp fishery in the South Atlantic region because it is while they occupy inshore estuarine waters that shrimp populations are most vulnerable to habitat disturbance (South Atlantic Fishery Management Council 1993). Although com- 
mercial landings of these shrimp have been linked to the amount of vegetated intertidal habitat in a region (Turner 1977), the mechanism underlying the relationship remains unresolved.

Salt marshes, characterized by broad expanses of vegetated intertidal wetlands interspersed by networks of tidal channels (e.g. Ragotzkie \& Bryson 1955), comprise most of the estuarine habitat used by juvenile penaeid shrimp at temperate latitudes. This productive and structure-rich environment is believed to offer estuarine nekton both a rich foraging habitat and a refuge from predators (Boesch \& Turner 1984, Minello \& Zimmerman 1991), qualities that conform to the general definition of essential fish habitat (Benaka 1999). Litopenaeus setiferus regularly uses vegetated intertidal marshes of the region when that habitat is tidally inundated (Mayer 1985, Kneib 1995, 2000), but also seems averse to the risk of stranding because it is among the first of the marsh nekton assemblage to return to tidal creeks on ebb tides (Kneib \& Wagner 1994).

Continued growth of human populations in and around the estuarine portions of watersheds have placed increased pressure on regulators and managers to resolve conflicting demands resulting from changing patterns in land and resource use. Should all areas of tidal marsh within this region be considered essential habitat for white shrimp, and thus be protected from anthropogenic impacts, or is there a way of refining the definition by relating structural features of the habitat to patterns of production and use by estuarinedependent fishery species? To begin addressing this question, we needed a mechanistic framework within which processes controlling habitat use could be related to one or more simple habitat metrics. Kneib (1994) proposed, and later extended (Kneib 1997, 2000), a trophic relay hypothesis that linked ecological processes influencing growth, survival and behavior of estuarine nekton to prominent physical features of the marsh landscape, such as the degree of reticulation in hierarchical sub-systems of tidal creeks that channel water through the system. Here, we applied that framework to determine whether the spatial distribution and abundance of juvenile white shrimp within shallow subtidal channels could be related to variation in the complexity of intertidal creek channels or the amount of intertidal area within the adjacent marsh landscape. If variation in habitat use by juvenile shrimp could be linked to variation in a simple spatial metric (e.g. amount of channel edge per unit area), it would contribute to refining the definition of essential fish habitat for this species and provide an important practical tool for coastal land and resource managers who could use it to predict general impacts of landscape changes on shrimp production.

\section{MATERIALS AND METHODS}

Study sites. All samples were collected from tidal creek subsystems of the Duplin River, the principal tidal channel draining the marshes of the Sapelo Island National Estuarine Research Reserve (SINERR) on the west side of Sapelo Island, Georgia (Fig. 1). The Duplin River drainage $\left(\sim 11 \mathrm{~km}^{2}\right)$ includes almost $10 \mathrm{~km}^{2}$ of intertidal salt marsh, mudflat and minor channels that are inundated twice daily by tides with a mean range of $2.1 \mathrm{~m}$ (Wadsworth 1980). The SINERR is representative of the polyhaline component of a continuous 8 to $12 \mathrm{~km}$ wide strip of tidal marsh liberally dissected by creeks, river channels and sounds that separate the sea islands of Georgia from the mainland (Ragotzkie $\&$ Bryson 1955). These salt marsh complexes are connected to the ocean through numerous tidal inlets between the barrier islands. The Duplin River is an elongated tidal lagoon connected to Doboy Sound, which receives freshwater input primarily from local upland runoff and flows from the Altamaha River to the south via several interconnected tidal rivers and creeks (Ragotzkie \& Bryson 1955). Average weekly water temperatures in the Duplin River drainage vary

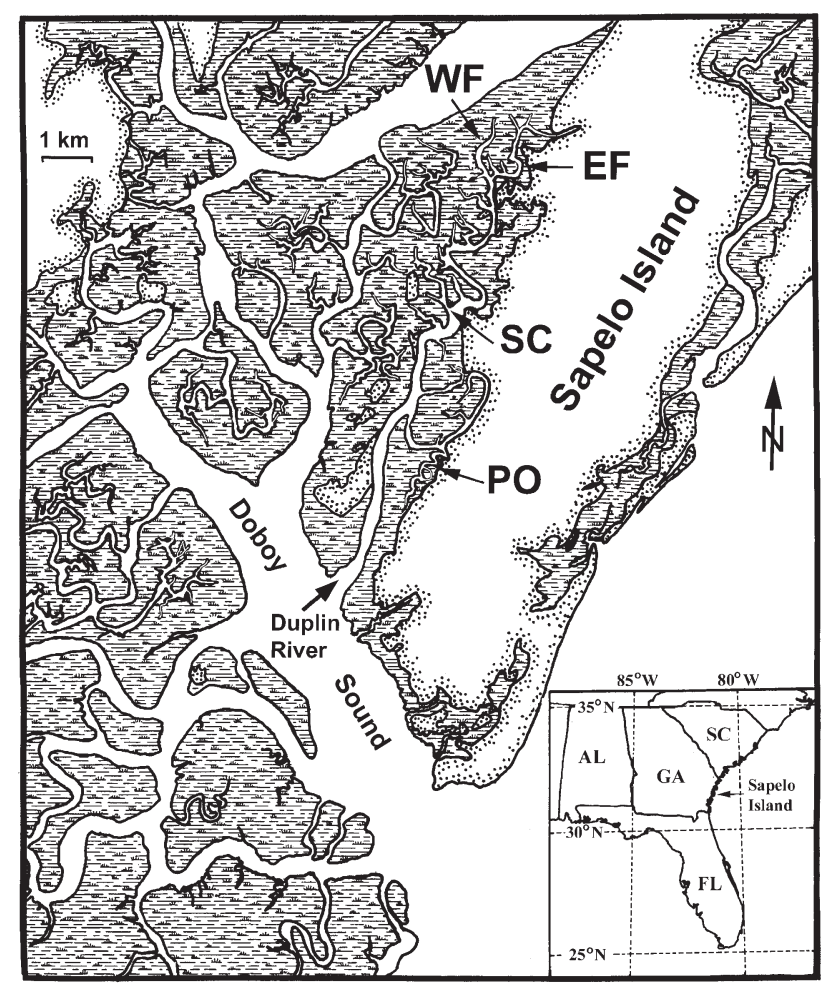

Fig. 1. Map of the salt marsh estuary in the vicinity of Sapelo Island, Georgia, USA, showing locations of the tidal creek sub-systems within the tidal drainage of the Duplin River. PO: Post Office Creek; SC: Stacey Creek; EF, WF: East and West Forks of the Duplin River, respectively 
seasonally between 10 and $30^{\circ} \mathrm{C}$, and salinity normally ranges from 15 to 30 ppt (Kneib 1995). Smooth cordgrass Spartina alterniflora is the dominant emergent vegetation in the local marshes.

Tidal creek sub-systems included in the study were Post Office Creek (PO) and Stacey Creek (SC) in 1998, and the east and west forks (EF and WF) of the upper Duplin River in 1999 (Fig. 1). Logistic constraints precluded sampling more than 2 creek sub-systems per season, and different sub-system pairs were chosen in each of the 2 years to broaden the spatial perspective of the study. PO and SC are located in the lower and middle reaches of the Duplin River, respectively, while $\mathrm{EF}$ and WF comprise the upper reaches of the entire Duplin drainage system. The mainstem length of each subtidal creek was divided into a series of $200 \mathrm{~m}$ segments, the boundaries of which were marked with wooden posts inserted in the sediments of the adjacent marsh to identify sampling stations. The number of sampling stations within a creek sub-system depended on the navigable length of the subtidal channel. There were 13 stations in Post Office Creek, 11 in Stacey Creek, 9 in the East Fork, and 7 in the West Fork of the Upper Duplin River.

Landscape characteristics. A set of high-resolution, large-format $(23 \times 23 \mathrm{~cm})$ black and white negatives (1:16000 scale) from an aerial survey of the region in December 1989 were used to measure the following physical characteristics of the landscape associated with each tidal sub-system: total drainage area, subtidal area and edge, and intertidal area and edge. Total drainage area was defined as the entire intertidal and subtidal area within the watershed of a tidal subsystem, exclusive of any upland habitat. Subtidal area was defined as habitat that remained inundated by water at low tide and maintained a continuous aquatic connection to the open waters of the estuary. Subtidal area was subtracted from total drainage area to obtain intertidal drainage area. The aerial photos were taken near low tide, so creek channels that appeared to retain water with an uninterrupted connection to the Duplin River were defined as subtidal, while those that appeared completely drained or contained isolated pools of water at low tide were defined as intertidal. Subtidal edge was a linear measure (in meters) of the physical interface between subtidal creek channels and vegetated marsh; likewise, intertidal edge was the interface between vegetated marsh and adjacent intertidal creek channels. A grid of $2 \times 2 \mathrm{~cm}$ squares (1 square scaled to $10.24 \mathrm{ha}$ ) printed on a transparency was placed over the aerial photos and the composite image (e.g. Fig. 2) was scanned into Adobe ${ }^{\circledR}$ PhotoShop ${ }^{\circledR}$ (Version. 5.5, Adobe Systems Inc.) using a Microtek Scan Maker ${ }^{\circledR}$ III scanner. The image was viewed on a computer monitor at an effective enlargement of

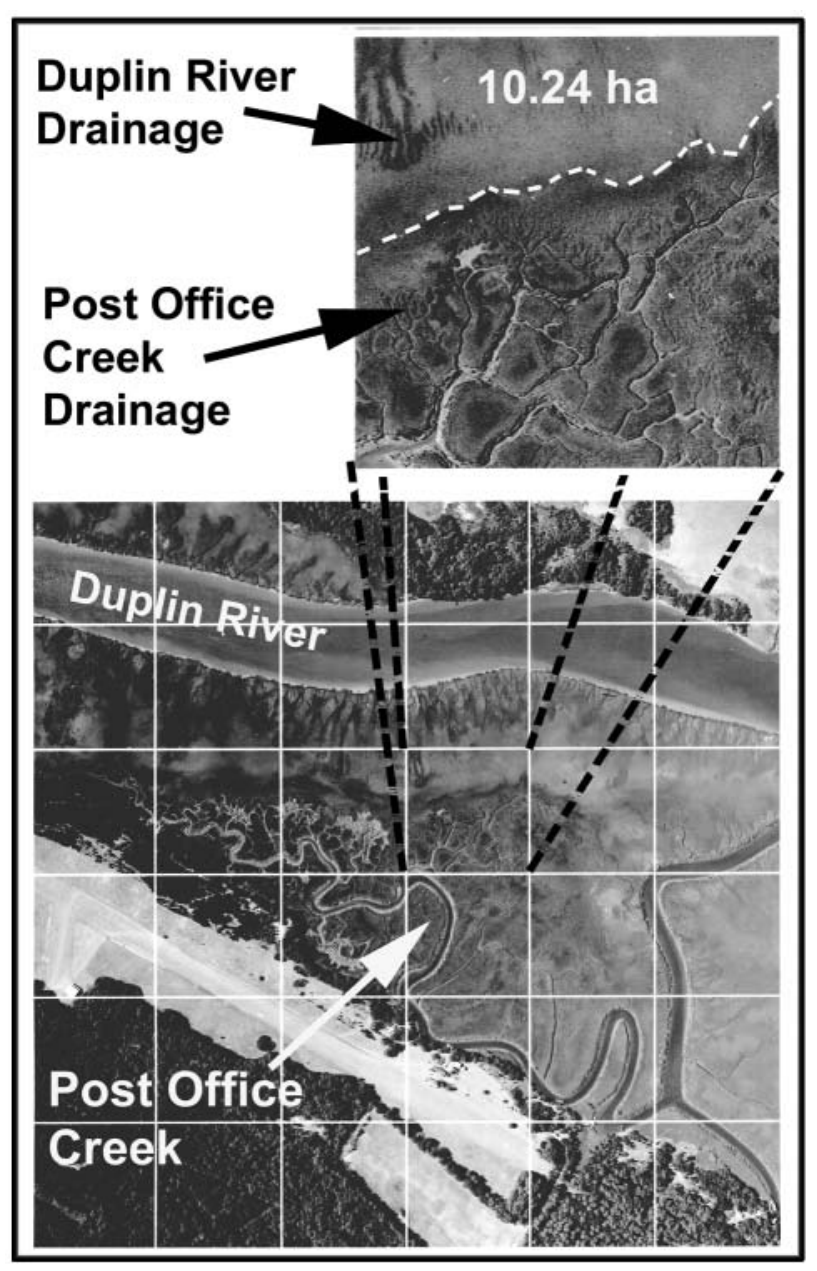

Fig. 2. Aerial photograph of the Post Office Creek sub-system (PO) and the level of detail used to measure landscape characteristics within a superimposed grid of square plots. The white dashed line in the expanded view of a single grid square (10.24 ha) is the demarcation between the tidal drainage of the PO sub-system and the main channel of the Duplin River

$9.5 \times$ the size of the original negative. Distances and areas were digitized by tracing the outlines of creek features directly from the enlarged image into the software program Sigma Scan Pro $^{\circledR}$ (Version. 4.0, SPSS, Inc.). Sampling stations within each creek sub-system were grouped as equitably as possible into upper, middle, and lower reaches. Variation in physical landscape characteristics was evaluated for the drainage area associated with each reach separately.

Field sampling. To ensure that the population was restricted to the creek channels, shrimp were sampled with a $1.52 \mathrm{~m}$ diameter cast net (ca. $1 \mathrm{~cm}$ mesh) during the 2 to $3 \mathrm{~h}$ period on each side of low tide when the vegetated intertidal marsh was not inundated. 
The samples were collected as part of a mark-recapture study, the findings of which are reported elsewhere (Webb 2000, Webb \& Kneib unpubl. data). Sampling effort consisted of 10 haphazard casts of the net along the edge of the tidal creek within each station. Sampling began $6 \mathrm{~d}$ after the midpoint of an initial $3 \mathrm{~d}$ monthly marking period and then at $3 \mathrm{~d}$ intervals for the next $15 \mathrm{~d}$, for a total of 6 sampling dates per month. Data from the marking effort were not included because we selected and measured only shrimp that were 40 to $80 \mathrm{~mm}$ TL (total length: tip of rostrum to end of telson) during marking episodes. Inclement weather and occasional equipment failure sometimes prevented adherence to the sampling schedule, so some months were represented by $<6$ samples.

Contents of the sample (10 casts) were placed in a separate plastic bag for each station and transported on ice to the laboratory. Juvenile shrimp were identified and a sub-sample from each station (every tenth individual) was measured to estimate size distributions within and between creeks. If fewer than 100 shrimp were taken at a station, all individuals were measured. Sex was not determined. Sampling commenced in early July, when juvenile white shrimp first became abundant in the marshes, and was terminated in midNovember, when their numbers declined substantially with the seasonal migration out of the nursery. Salinity, water temperature, and dissolved oxygen (DO) were measured near the surface $(<1 \mathrm{~m}$ depth) at the mouth of the tidal creek on each sampling day using a YSI Model 58 DO meter. Supplemental data on changes in temperature, rainfall, salinity, DO, and solar radiation during the study were available from 8 permanent monitoring stations in the Duplin River system - 2 maintained by the University of Georgia Marine Institute and 6 maintained by our group in support of other research projects.

Statistical analyses. Most of the statistical analyses were computed using Version 8.0 of the computer software package Systat ${ }^{\circledR}$ (SPSS, Inc.). When parametric tests were performed, residuals were analyzed to detect deviations from assumptions of normality and variance homogeneity. Levene's test (Snedecor \& Cochran 1980) was applied to evaluate the assumption of variance homogeneity among groups. When this assumption was violated, the data were log-transformed. If the assumptions were still not met, then an appropriate non-parametric method was applied (e.g. KruskalWallis 1-way analysis of variance, ANOVA). An experiment-wise error rate $(\alpha)$ of 0.05 was adopted in setting the critical values used to reject the null hypothesis in all statistical tests.

Two-sample $t$-tests were used to compare spatial and temporal variation in water temperature, salinity, and dissolved oxygen between creeks and between years.
Catch per unit effort (CPUE, the combined catch from 10 casts station $^{-1}$ ) and average sizes of shrimp per station and sampling date were grouped into upper, middle, and lower reaches (from creek headwaters to the mouth) to evaluate the spatial distribution of shrimp within creeks. Regression analyses were performed to test for linear relationships between creek edge and $\sqrt{ }$ (drainage area), and between CPUE and both of the previous landscape variables.

The mean sizes of shrimp in each creek reach were calculated as a weighted average of the number of individuals caught station $^{-1}$ within a reach. A 1-way ANOVA was used to test for differences in mean CPUE and mean size of shrimp among creek reaches, using months (pooling sampling dates within month) as replicate observations. When statistically significant differences were found, Tukey's multiple-comparison procedure was applied to determine which tidal creek reaches differed from the others. The nonparametric Kolmogorov-Smirnov test (Sokal \& Rohlf 1995) was used in pair-wise comparisons of length frequency histograms ( $5 \mathrm{~mm}$ size classes) grouped by creek reach (upper, middle, and lower), months within years, and by year (1998 and 1999).

Paired $t$-tests were used to compare CPUE between years and between pairs of creek sub-systems within years using average monthly values as observations. Data from August 1998 were excluded from these tests because equipment difficulties severely impacted the total catch $(<100$ individuals $)$ of shrimp from Stacey Creek in that month. Variance heterogeneity in the size data among the remaining groups could not be corrected by transformation, so the non-parametric Mann-Whitney $U$-test was applied to compare the ranked average sizes of shrimp between creek subsystems within years.

\section{RESULTS}

\section{Physical variables}

Mean values of water temperature, salinity, and DO measurements taken near low tide at the mouth of each tidal creek were similar between creeks within years (Table 1). In 1998, measurements of temperature ranged from 18.9 to $33.4^{\circ} \mathrm{C}$, salinity from 18.2 to 28.0 ppt, and DO from 1.44 to $11.32 \mathrm{mg} \mathrm{l}^{-1}$. In 1999, ranges for temperature, salinity and DO values were 15.0 to $33.4^{\circ} \mathrm{C}, 23.9$ to $32.5 \mathrm{ppt}$, and 0.8 to $7.1 \mathrm{mg} \mathrm{l}^{-1}$, respectively. Temperature maxima at all sites occurred in July or August and declined through the autumn months. Results of $t$-tests using separate variance estimates provided no evidence for a significant difference in either mean temperature $(t=-0.14, \mathrm{df}=134.0$, 
Table 1. Monthly (mean $\pm \mathrm{SD}$ ) of physical environmental variables measured near the mouth of each tidal creek sub-system (Duplin River, Sapelo Island). Post Office and Stacey Creeks were sampled in 1998, and the East and West Forks were sampled in 1999. Number of monthly measurements in each creek is in parentheses. DO: dissolved oxygen

\begin{tabular}{|c|c|c|c|c|c|}
\hline Environmental variables & July & August & September & October & November \\
\hline \multicolumn{6}{|l|}{ Post Office Creek } \\
\hline Water temp. $\left({ }^{\circ} \mathrm{C}\right)$ & $31.0 \pm 1.0(4)$ & $28.8 \pm 1.1(9)$ & $29.0 \pm 2.3(8)$ & $23.8 \pm 3.5(8)$ & $20.1 \pm 0.8(5)$ \\
\hline Salinity (ppt) & $23.0 \pm 4.0(4)$ & $25.3 \pm 1.1(9)$ & $24.6 \pm 1.2(8)$ & $23.5 \pm 0.4(8)$ & $25.9 \pm 0.3$ \\
\hline $\mathrm{DO}\left(\mathrm{mg} \mathrm{l}^{-1}\right)$ & $8.0 \pm 3.2(4)$ & $3.6 \pm 1.1(9)$ & $4.7 \pm 1.3(8)$ & $5.9 \pm 1.6(8)$ & $3.7 \pm 1.4$ \\
\hline \multicolumn{6}{|l|}{ Stacey Creek } \\
\hline Water temp. $\left({ }^{\circ} \mathrm{C}\right)$ & $29.5 \pm 1.6(6)$ & No data $(0)$ & $28.2 \pm 1.3(5)$ & $25.5 \pm 1.9(9)$ & $20.7 \pm 1.8(6)$ \\
\hline Salinity (ppt) & $25.8 \pm 1.3(6)$ & No data $(0)$ & $25.8 \pm 1.7(5)$ & $23.2 \pm 0.6(9)$ & $25.8 \pm 0.5(6)$ \\
\hline $\mathrm{DO}\left(\mathrm{mg} \mathrm{l}^{-1}\right)$ & $3.8 \pm 1.8(6)$ & No data (0) & $3.9 \pm 1.6(5)$ & $4.1 \pm 1.6(9)$ & $5.4 \pm 0.9(6)$ \\
\hline \multicolumn{6}{|l|}{ East Fork } \\
\hline Water temp. $\left({ }^{\circ} \mathrm{C}\right)$ & $30.7 \pm 1.8(8)$ & $30.7 \pm 1.1(9)$ & $25.8 \pm 2.2(3)$ & $24.0 \pm 2.0(9)$ & $19.4 \pm 2.3(6)$ \\
\hline Salinity (ppt) & $27.1 \pm 0.8(8)$ & $28.6 \pm 1.2(9)$ & $29.3 \pm 2.8(3)$ & $28.0 \pm 0.6(9)$ & $27.0 \pm 0.3(6)$ \\
\hline $\mathrm{DO}\left(\mathrm{mg} \mathrm{l}^{-1}\right)$ & $4.5 \pm 1.5(8)$ & $2.9 \pm 1.6(9)$ & $3.6 \pm 0.6(3)$ & $3.2 \pm 1.4(9)$ & $5.3 \pm 0.3(6)$ \\
\hline \multicolumn{6}{|l|}{ West Fork } \\
\hline Water temp. $\left({ }^{\circ} \mathrm{C}\right)$ & $30.4 \pm 1.4(9)$ & $31.1 \pm 1.3(9)$ & $26.6 \pm 2.0(7)$ & $24.1 \pm 3.5(7)$ & $18.3 \pm 2.2(8)$ \\
\hline Salinity (ppt) & $26.8 \pm 0.4(9)$ & $29.3 \pm 1.0(9)$ & $30.3 \pm 2.1(7)$ & $28.2 \pm 0.4(7)$ & $26.7 \pm 1.2(8)$ \\
\hline $\mathrm{DO}\left(\mathrm{mg} \mathrm{l}^{-1}\right)$ & $4.4 \pm 1.8(9)$ & $4.9 \pm 1.2(9)$ & $2.7 \pm 1.1(7)$ & $5.0 \pm 1.0(7)$ & $4.4 \pm 1.4$ \\
\hline
\end{tabular}

$\mathrm{p}=0.80)$ or $\mathrm{DO}(t=1.82, \mathrm{df}=115.9, \mathrm{p}=0.07)$ in samples between years. However, mean salinity was significantly $(t=-11.63, \mathrm{df}=122.7, \mathrm{p}<0.01)$ higher in 1999 (28.1 ppt) than in 1998 (24.8 ppt). Cumulative annual rainfall was $83.9 \mathrm{~cm}$ in 1998 and $82.9 \mathrm{~cm}$ in 1999 (University of Georgia Marine Institute [UGAMI] monitoring station data). These values are below normal levels of precipitation, which averaged ca. 125 to $150 \mathrm{~cm} \mathrm{yr}^{-1}$ from 1968 to 1994 (UGAMI weather station data).

Table 2. Drainage area and amount of channel edge within each reach of the 4 tidal creek sub-systems

\begin{tabular}{|c|c|c|c|c|}
\hline \multirow[t]{2}{*}{ Reach } & \multicolumn{2}{|c|}{ Drainage area $\left(\mathrm{m}^{2}\right)$} & \multicolumn{2}{|c|}{ Edge (m) } \\
\hline & Subtidal & Intertidal & Subtidal & Intertidal \\
\hline \multicolumn{5}{|c|}{ Post Office Creek } \\
\hline Upper & 22304 & 279611 & 3465 & 18029 \\
\hline Middle & 26409 & 227344 & 4062 & 15065 \\
\hline Lower & 28861 & 188401 & 3161 & 4848 \\
\hline \multicolumn{5}{|c|}{ Stacey Creek } \\
\hline Upper & 19430 & 252698 & 3021 & 17966 \\
\hline Middle & 15620 & 153634 & 2513 & 10863 \\
\hline Lower & 13769 & 130599 & 1969 & 9103 \\
\hline \multicolumn{5}{|c|}{ East Fork } \\
\hline Upper & 27047 & 588103 & 2879 & 37955 \\
\hline Middle & 49725 & 273849 & 2735 & 27475 \\
\hline Lower & 101241 & 154760 & 6598 & 9272 \\
\hline \multicolumn{5}{|c|}{ West Fork } \\
\hline Upper & 25234 & 572207 & 3134 & 31646 \\
\hline Middle & 16636 & 148,185 & 1253 & 2466 \\
\hline Lower & 72011 & 214595 & 3986 & 14316 \\
\hline
\end{tabular}

\section{Drainage area and channel edge}

Table 2 summarizes the data on drainage area and amount of edge within each of the 4 tidal sub-systems. The East and West Forks of the Duplin River had substantially larger drainage areas than the other pair of sub-systems. However, all sub-systems were similar with respect to the ratio of channel edge to drainage area. Using data from each of the 3 reaches in all 4 subsystems as observations, we regressed $\sqrt{\text { (intertidal drain- }}$ age area) on the total amount of creek edge (intertidal + subtidal $)$ and detected a significant $\left(F_{1,10}=48.7\right.$, $\left.\mathrm{p}<0.001, \mathrm{R}^{2}=0.81\right)$ positive linear relationship between these 2 variables. Edge and drainage area both usually increased from the lower to upper reaches of each sub-system. The only exception was in the West Fork of the Duplin River, where there was less edge and intertidal drainage area in the middle than the lower reach (Table 2).

\section{Within-creek comparisons}

Samples collected in 1998 included 35740 and 20077 juvenile white shrimp from PO and SC, respectively. In the following year, samples from EF and WF contained 66843 and 78724 individuals, respectively. We pooled data from sampling dates within months and creek reach, using monthly average CPUE values as concurrent replicates to compare shrimp abundance among creek reaches. The results demonstrate a clear trend for greater catches of shrimp in the upper reaches, with 
Table 3. Litopenaeus setiferus. Results of multiple paired $t$-tests (Bonferroni adjustment applied) to compare mean CPUE between reaches within each tidal creek sub-system. ns: not significant; $\mathrm{p}>0.05$

\begin{tabular}{|c|c|c|c|c|c|c|}
\hline \multirow[t]{2}{*}{ Creek sub-system } & \multicolumn{3}{|c|}{$\begin{array}{l}\text { Mean CPUE by } \\
\text { creek reach }\end{array}$} & \multicolumn{3}{|c|}{$\begin{array}{l}\text { Bonferroni-adjusted probability associated with } \\
\text { each paired } t \text {-test }\end{array}$} \\
\hline & Upper & Middle & Lower & $\begin{array}{l}\text { Upper vs } \\
\text { middle }\end{array}$ & $\begin{array}{l}\text { Upper vs } \\
\text { lower }\end{array}$ & $\begin{array}{l}\text { Middle vs } \\
\text { lower }\end{array}$ \\
\hline Post Office Creek & 26.7 & 9.8 & 3.2 & $<0.001$ & $<0.001$ & $<0.001$ \\
\hline Stacey Creek & 21.4 & 5.9 & 5.9 & 0.014 & 0.015 & ns \\
\hline East Fork & 45.7 & 33.3 & 17.9 & ns & $<0.001$ & $<0.001$ \\
\hline West Fork & 52.0 & 52.7 & 20.7 & ns & $<0.001$ & $<0.001$ \\
\hline
\end{tabular}

abundance declining toward the mouth of each subsystem (Table 3).

CPUE, intertidal marsh edge, and the intertidal drainage area associated with each sampling station tended to increase from the lower to the upper reaches of all creeks, except for WF, where intertidal edge and drainage area were least in the middle rather than lower reaches (Fig. 3). The data point from the middle reach of the WF was identified SYSTAT $^{\circledR}$ linear regression procedure) as a statistical outlier in relationships between CPUE and amount of intertidal edge (Studentized residual $=7.222$ ) and between CPUE and $\sqrt{ }$ (intertidal drainage area) (Studentized residual $=5.943$ ). When it was omitted from the analyses, regressions of mean CPUE (pooled across months and stations within each creek reach) on the amount of intertidal creek edge and $\sqrt{ }$ (intertidal drainage area) both resulted in significant linear relationships that accounted for similar amounts of the variation in mean CPUE (Fig. 3). Similar regression analyses of CPUE on subtidal edge $\left(F_{1,9}=0.013 ; \mathrm{p}=0.912\right)$ and $\sqrt{ }$ (subtidal drainage area) $\left(F_{1,9}=0.084 ; \mathrm{p}=0.779\right)$ showed no significant linear relationships.

Size distributions of shrimp in the upper reaches were significantly different (Kolmogorov-Smirnov test, $\mathrm{p}<0.01$ ) from those in the lower reaches of all creeks. Comparison of length-frequency histograms showed that differences were due to a higher proportion of small $(<65 \mathrm{~mm}$ TL) shrimp in the upper reaches of each creek sub-system (Fig. 4). Mean sizes of shrimp tended to decrease from the lower to upper reaches of most, but not all, tidal creek sub-systems (Table 4). Even when differences in mean sizes among reaches were significant, the magnitude of those differences usually was relatively small (a few $\mathrm{mm}$ ). Size structure of the populations varied through time, reflecting periodic recruitment of young juveniles, their subsequent growth, and later emigration from the creek sub-systems. This recruitment-emigration dynamic may have masked or minimized any temporal trend in the mean size of shrimp between creek reaches. For example, no differences in mean size were detected among reaches in the WF subsystem (Table 4).
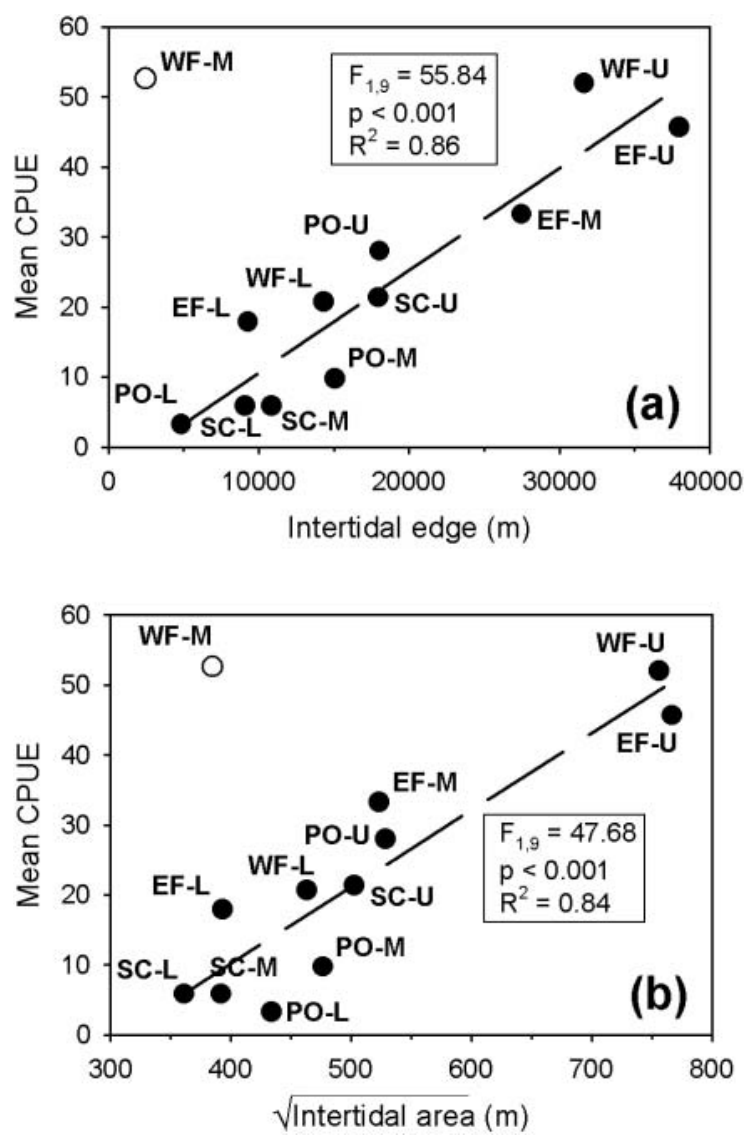

Fig. 3. Litopenaeus setiferus. Linear relationships between mean catch per unit effort (CPUE) of juvenile shrimp from creek channels at low tide and (a) amount of intertidal edge and (b) square root of the intertidal area associated with the upper (-U), middle (-M) and lower (-L) reaches of each tidal creek sub-system (PO: Post Office Creek; SC: Stacey Creek; EF, WF: East and West Forks of the Duplin River respectively). The open circle (WF-M) in each panel was considered an outlier and was omitted from the analyses 


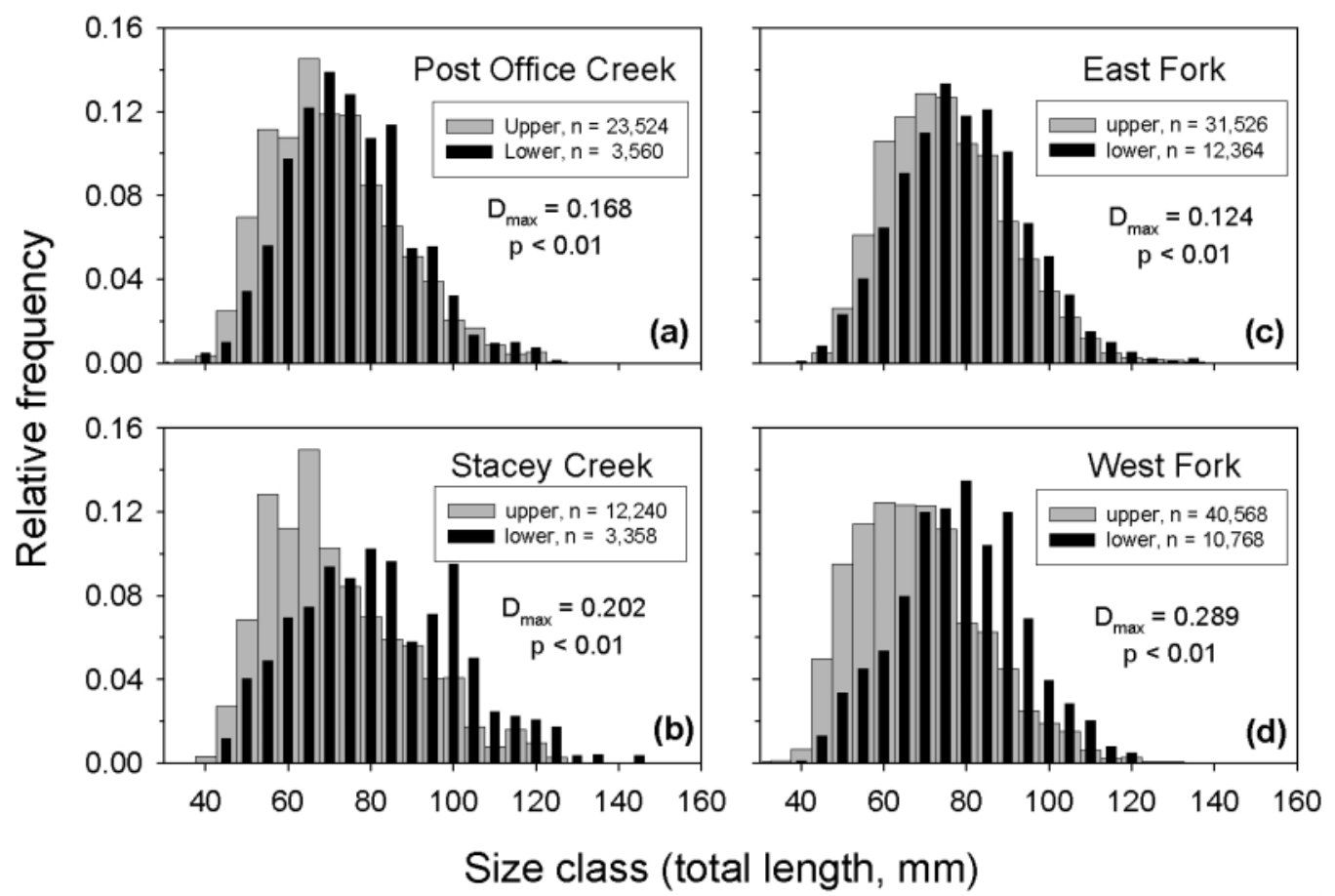

Fig. 4. Litopenaeus setiferus. Pair-wise comparisons of juvenile size distributions from the upper and lower reaches of Post Office Creek, Stacey Creek, East Fork and West Fork of the Duplin River. The number of individuals associated with each size distribution is shown along results of the Kolmogorov-Smirnov procedure ( $D_{\max }$ statistic and probability) testing the null hypothesis that shrimp from each reach within a creek sub-system were drawn from the same population

\section{Between-creek comparisons}

The trend of higher shrimp density (CPUE) in the upper reaches of individual tidal creek sub-systems may be a hierarchical feature of the estuarine marsh landscape that extends to the entire Duplin drainage system. CPUE in the EF and WF, which together constitute the upper reaches of the Duplin River (Fig. 1), was substantially greater than in samples from the middle reach of the Duplin drainage, which included PO and SC. Results of a $t$-test performed on transformed data $\left(\log _{10}\right.$ CPUE) showed that (mean \pm SD) abundance was significantly $(t=10.28$, df $=267, \mathrm{p}<$ $0.001)$ greater in sub-systems in the upper reaches
(1.42 $\pm 0.43, \mathrm{n}=147)$ compared to the middle reaches $(0.88 \pm 0.43, \mathrm{n}=122)$ of the Duplin River system.

Independent evidence from quantitative samples of juvenile shrimp taken in the vegetated intertidal marsh at high tide supports a pattern of spatial variation in abundance within the entire Duplin River system consistent with our description. Juvenile white shrimp collected in flume-weirs (Kneib unpubl. data, see Kneib 1991 for description of method) at sites in the upper, middle and lower reaches of the Duplin River drainage in 1999 showed a clear pattern of increasing density from the lower to the upper reaches (Fig. 5).

Table 4. Litopenaeus setiferus. Results of multiple paired $t$-tests (Bonferroni adjustment applied) to compare mean size of juvenile shrimp between reaches within each tidal creek sub-system. TL: total length; ns: not significant; $p>0.05$

\begin{tabular}{|c|c|c|c|c|c|c|}
\hline \multirow[t]{2}{*}{ Creek sub-system } & \multicolumn{3}{|c|}{ Mean shrimp size (TL, mm) } & \multicolumn{3}{|c|}{ Bonferroni-adjusted probability } \\
\hline & Upper & Middle & Lower & $\begin{array}{l}\text { Upper vs } \\
\text { middle }\end{array}$ & $\begin{array}{l}\text { Upper vs } \\
\text { lower }\end{array}$ & $\begin{array}{l}\text { Middle vs } \\
\text { lower }\end{array}$ \\
\hline Post Office Creek & 68.9 & 72.3 & 73.2 & 0.013 & 0.005 & ns \\
\hline Stacey Creek & 68.7 & 72.3 & 73.2 & 0.005 & 0.002 & ns \\
\hline East Fork & 70.6 & 74.9 & 80.5 & ns & $<0.001$ & 0.010 \\
\hline West Fork & 77.2 & 77.5 & 78.5 & ns & ns & ns \\
\hline
\end{tabular}




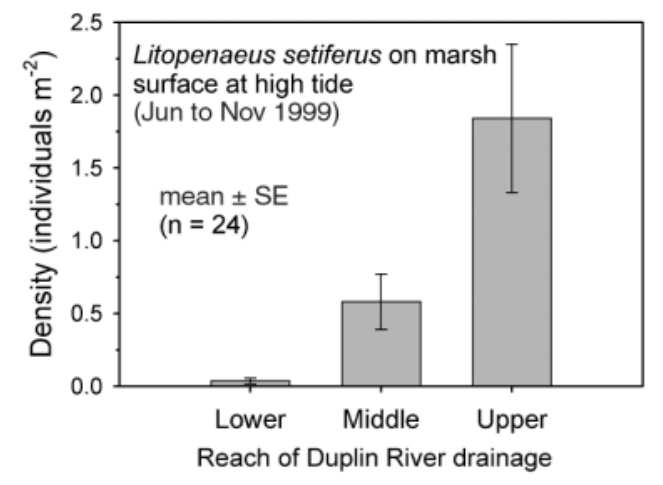

Fig. 5. Litopenaeus setiferus. Mean densities of juvenile white shrimp from 24 flume-weir (see Kneib 1991) samples collected in 1999 from the marsh surface at high tide in the lower, middle and upper reaches of the Duplin River tidal drainage

\section{DISCUSSION}

Previous studies have characterized penaeid shrimp abundance and distribution in estuaries with respect to temperature and salinity gradients (Wenner \& Beatty 1993, Vance et al. 1997), substratum (Rulifson 1981), type and areal extent of estuarine vegetation (Turner 1977, Vance et al. 1990, Haywood et al. 1995), food resources (Mayer 1985, McTigue \& Zimmerman 1998), and interspecific interactions (Minello \& Zimmerman 1991). Here we focused on the relationship between spatial distribution patterns of white shrimp Litopenaeus setiferus, and the physical structure of the estuarine marsh landscape that serves as their principal nursery habitat.

\section{Distribution and abundance within the tidal marsh landscape}

Our finding that juvenile shrimp were smaller and more abundant in the upper reaches of tidal creeks is consistent not only with previous observations of the same species in Georgia (Hackney \& Burbanck 1976), but with reported penaeoid shrimp distributions in mangrove estuaries of Australia (e.g. Vance et al. 1990) as well as distributions of juvenile fishes within a variety of other tidal estuarine landscapes (e.g. Weinstein 1979, Rozas \& Odum 1987). These and similar earlier observations support a general and long-standing tenet that there are ontogenetic shifts in habitat use along estuarine salinity gradients, with smaller individuals found in the lower salinity waters farther inland and a general movement toward higher salinity waters with increasing size and age (Zein-Eldin \& Renaud 1986, Wenner \& Beatty 1993).
We propose that variation in salinity per se is not the only, nor perhaps even the principal, mechanism controlling the distribution of juvenile white shrimp in Georgia's tidal marshes. Instead, variation in the extent and physical complexity of the adjacent marsh landscape may underlie the observed patterns of abundance in subtidal creek channels. The pattern in complexity of tidal creeks and distribution of juvenile white shrimp is maintained at different spatial scales within the estuary. Creek edge and intertidal drainage area were greatest not only in the upper reaches of each individual creek sub-system studied here, but also in the upper reaches of the larger Duplin River system. The EF and WF sub-systems together compose the upper reaches of the Duplin River, while PO and $\mathrm{SC}$ are components of the middle reaches (Fig. 1). Spatial patterns formed by hierarchical networks of channels dissecting the vegetated marsh landscape have been classified along a gradient of drainage density from simple to complex (Frey \& Basan 1978, Wadsworth 1980). Areas of high drainage density form a complex pattern of many, often interconnected, tidal creeks while areas of low drainage density include simple creek channels with few bifurcations. Our findings show that juvenile shrimp abundance correlate with this variation in landscape complexity at spatial scales that include both individual creek (km) sub-systems (Fig. 3) and the broader (tens of km) Duplin River system (Fig. 5).

Salinity has been considered an important factor in the distribution of juvenile white shrimp within estuaries (e.g. Zein-Eldin \& Renaud 1986, Wenner \& Beatty 1993), but it is unlikely that the inter-annual difference in salinity we observed could account for the difference in abundance of shrimp between reaches of the Duplin River. First, salinity was within the polyhaline range (18 to $30 \mathrm{ppt}$ ) at all sites (Table 1) and, although statistically significant, the difference between years was relatively small (ca 3.3 ppt) because drought conditions prevailed in both years. Second, contrary to the existing tenet that juvenile white shrimp perform best at lower estuarine salinities (e.g. Zein-Eldin \& Renaud 1986), CPUE was greater at the higher mean salinities observed at the EF and WF sites in 1999 compared to sites (PO and SC) sampled in 1998.

The broad-scale spatial difference in shrimp abundance we have describe could, of course, be attributable to inter-annual variation in abundance because creeks in the upper (WF, EF) and middle (PO, SC) reaches of the Duplin River were sampled in different years. If this were simply the result of temporal variation, one might expect such a large inter-annual difference in abundance of juvenile shrimp within the nursery (ca. 61\% greater in 1999 than in 1998) to be reflected in the local fishery, but annual commercial white shrimp landings in Georgia 
(July to December) differed by only $5 \%$ between 1998 and 1999 (averaging 171.5 and $180.7 \mathrm{t}$ in each year respectively; Georgia Department of Natural Resources, J. Califf pers. comm.), and a pairwise comparison of monthly landings provided no evidence for a statistically significant difference between years (paired $t=0.34$, df $=5, \mathrm{p}=0.74$ ). Considering all the available evidence, we believe the difference in abundance of shrimp observed between years in the present study was largely the result of spatial variation in habitat use within the regional landscape rather than inter-annual variation.

Turner (1977) argued that commercial penaeid shrimp landings worldwide were directly and positively related to the area of intertidal vegetation associated with coastal wetlands. There is not complete agreement about the affinity of white shrimp for vegetated estuarine habitats. In some areas, the species does not select as strongly for vegetated habitat as other penaeids such as the brown shrimp Farfantepenaeus aztecus (see Minello \& Zimmerman 1991), but numerous other studies have indicated that it utilizes the vegetated intertidal marsh extensively (Wenner \& Beatty 1993, Kneib 1994, Kneib \& Wagner 1994, Rozas \& Minello 1998), and even prefers this habitat when made available by tidal inundation (Rozas \& Zimmerman 2000). Our results also showed a direct positive relationship between intertidal drainage area and shrimp abundance in tidal creeks within the marsh landscape (Fig. 3b), but we are unable to separate the effects of a real extent of the marsh from that of the complexity of the environment as measured by the amount of creek edge (Fig. 3a) because intertidal edge and area were correlated. Complex tidal channel networks in the upper reaches of creeks seemingly preferred by juvenile shrimp and other smaller nekton may facilitate access to resources available only at high tide in the vegetated intertidal marsh (Rozas \& Minello 1998, Kneib 2000).

Tidal marshes may offer both a predator refuge and a rich foraging area for a variety of small nektonic organisms, including juvenile white shrimp (Boesch \& Turner 1984). Predation is a major source of natural mortality in juvenile shrimp populations (Minello \& Zimmerman 1991), and the spatial distribution patterns seen within tidal creeks in the present study could be a behavioral response to the presence of predators in the subtidal estuary or their tidal movements (e.g. Szedlmayer \& Able 1993). Predation risk is thought to decline with decreasing water depth and increasing individual size (Ruiz et al. 1993). During low tide, the shallow upper reaches of tidal creeks may serve as a refuge for young shrimp, because larger estuarine predators may be absent or infrequent visitors in these areas (Hackney \& Burbanck 1976, Rozas \& Odum 1987, Ruiz et al. 1993). The distribution patterns
(Table 3) and size gradients (Table 4, Fig. 4) observed indicate that juveniles utilize the shallow upper reaches of tidal creeks more extensively than deeper subtidal waters, moving downstream as they grow large enough to migrate back to the coastal ocean (Kneib 1997, Webb 2000).

Availability of food resources also may contribute to an explanation for the spatial distribution patterns of juvenile white shrimp within tidal creeks. Litopenaeus setiferus is an omnivore that consumes both live and dead plant and animal matter, including detritus (McTigue \& Zimmerman 1998). Plant detritus tends to accumulate in the headwaters of marsh creeks and along the marsh edge (Rozas \& Odum 1987), but alone it is unlikely to provide sufficient nutrition to support the rapid growth rate of juvenile penaeid shrimp (Boesch \& Turner 1984, Minello \& Zimmerman 1991, Kneib 1997). However, shrimp consume a variety of smaller invertebrate prey, whose populations can be supported by detrital food sources (e.g. Kneib et al. 1997) and are associated with the intertidal marsh (Mayer 1985, Kneib 1997). Intertidal populations of these prey species are available to shrimp and other aquatic foragers only when the marsh is tidally inundated. By associating with the upper reaches of tidal channels, where access to larger areas of intertidal marsh is enhanced by the presence of more edge, juvenile shrimp may be optimizing their foraging opportunities.

\section{Management implications}

Historically, management of shrimp stocks has focused on regulation of the fishery through restrictions on the methods, location and season of harvesting. However, loss of nursery habitat through the alteration and/or destruction of coastal wetlands is now recognized as a major threat to the viability of the wild penaeid shrimp fishery in the United States (South Atlantic Fisheries Management Council 1993). Anthropogenic alteration of estuarine shorelines through construction of bulkheads (Mock 1967), elimination or reduction of vegetated shorelines (Trent et al. 1976) and a variety of other methods of water control management in and around coastal wetlands (e.g. Herke 1995, Knudsen et al. 1996, Kneib 2000) have the potential to reduce production of shrimp and other fisheries species by hindering their access to critical habitats within the estuarine landscape. Structural changes in estuarine habitat almost always influence hydrologic characteristics (McIvor \& Rozas 1996, Mitsch \& Wilson 1996), which can then affect the amount of time that productive vegetated intertidal areas are available to penaeid shrimp and other nekton (Rozas 1995, Kneib 1997, 2000). 
Recent changes in federal legislation (under the Magnuson-Stevens Fishery Conservation and Management Act 1996) formally recognized the existence of essential fish habitat (EFH), and provided state and federal agencies with the means and the responsibility for strengthing protection of those portions of the estuarine nursery habitat in which alterations of landscape features have the potential to adversely impact the growth and survival of penaeid shrimp. Our findings contribute to a scientific rationale for refining the definition of essential fish habitat for penaeid shrimp to specifically accommodate consideration of accessibility to the intertidal marsh. We expect that loss or alteration of intertidal marsh and edge habitat associated with the upper reaches of tidal creeks would induce greater losses in production of Litopenaeus setiferus than if the same alterations were performed in the lower reaches of a tidal drainage system. Consideration of landscape features that promote access to the vegetated intertidal zone (i.e. increased amounts of edge) for shrimp and other nekton should be included in management decisions that affect essential fish habitats in coastal estuaries.

Acknowledgements. Many colleagues assisted in both the field and laboratory, but we are particularly grateful to K. Feeley, J. Kneib, and J. Spicer for field assistance on a regular basis. The primary source of funding for this research was a National Estuarine Research Reserve System Graduate Research Fellowship to S.R.W. (\#NA870R0284, Estuarine Reserves Division, Office of Ocean and Coastal Resource Management, NOS, NOAA) with matching funds from the University of Georgia Marine Institute. Additional financial support and the conceptual basis for the study were derived from National Science Foundation grant \#DEB-9629621. The Georgia Sea Grant College Program contributed supplemental funds for the purchase of equipment used in the project. This paper is Contribution No. 886 of the University of Georgia Marine Institute and is based on research conducted in partial fulfillment of the requirements for a Master's degree awarded to S.R.W.

\section{LITERATURE CITED}

Benaka LR (1999) Fish habitat: essential fish habitat and rehabilitation. Am Fish Soc Symp 22:xiii

Boesch DF, Turner RE (1984) Dependence of fishery species on salt marshes: the role of food and refuge. Estuaries 7(4A):460-468

Frey RW, Basan PB (1978) Coastal salt marshes. In: Davis RA Jr (ed) Coastal sedimentary environments. Springer-Verlag, New York, p 101-169

Hackney CT, Burbanck WD (1976) Some observations on the movement and location of juvenile shrimp in coastal waters of Georgia. Bull Ga Acad Sci 34:129-136

Haywood MDE, Vance DJ, Loneragan NR (1995) Seagrass and algal beds as nursery habitats for tiger prawns (Penaeus semisulcatus and $P$. esculentus) in a tropical Australian estuary. Mar Biol. 122:213-223
Herke WH (1995) Natural fisheries, marsh management, and mariculture: complexity and conflict in Louisiana. Estuaries 18(1A):10-17

Kneib RT (1991) Flume weir for quantitative collection of nekton from vegetated intertidal habitats. Mar Ecol Prog Ser 75:29-38

Kneib RT (1994) Spatial pattern, spatial scale, and feeding in fishes. In: Stouder DJ, Fresh KL, Feller RJ (eds) Theory and application in fish feeding ecology. University of South Carolina Press, Columbia, SC, p 171-185

Kneib RT (1995) Behaviour separates potential and realized effects of decapod crustaceans in salt marsh communities. J Exp Mar Biol Ecol 193:239-256

Kneib RT (1997) The role of tidal marshes in the ecology of estuarine nekton. Oceanogr Mar Biol Annu Rev 35: $163-220$

Kneib RT (2000) Salt marsh ecoscapes and production transfers by estuarine nekton in the southeastern U.S. In: Weinstein MP, Kreeger DA (eds) Concepts and controversies in tidal marsh ecology. Kluwer Academic Publishers, Group, Dordrecht, p 267-291

Kneib RT, Wagner SL (1994) Nekton use of vegetated marsh habitats at different stages of tidal inundation. Mar Ecol Prog Ser 106:227-238

Kneib RT, Newell SY, Hermeno HT (1997) Survival, growth and reproduction of the salt-marsh amphipod Uhlorchestia spartinophila reared on natural diets of senescent and dead Spartina alterniflora leaves. Mar Biol 128:423-431

Knudsen EE, Rogers BD, Paille RF, Herke WH (1996) Juvenile white shrimp growth, mortality, and emigration in weired and unweired Lousiana marsh ponds. N Am J Fish Manag 16:640-652

Kutkuhn JH (1966) The role of estuaries in the development and perpetuation of commercial shrimp resources. Am Fish Soc Spec Publ 3:16-36

Magnuson-Stevens Fishery Conservation and Management Act (1996) Public law 94-265 (16 U.S.C. 1801 et. seq.). United States Congress, Washington, DC, USA

Mayer MA (1985) Ecology of juvenile white shrimp, Penaeus setiferus Linnaeus, in the salt marsh habitat. MS thesis, Georgia Institute of Technology, Atlanta, GA

McIvor CC, Rozas LP (1996) Direct nekton use of intertidal saltmarsh habitat and linkage with adjacent habitats: a review from the southeastern United States. In: Nordstrom KF, Roman CT (eds) Estuarine shores: evolution, environments and human alterations. John Wiley \& Sons, New York, p 311-334

McTigue TA, Zimmerman RJ (1998) The use of infauna by juvenile Penaeus aztecus Ives and Penaeus setiferus (Linnaeus). Estuaries 21:160-175

Minello TJ, Zimmerman RJ (1991) The role of estuarine habitats in regulating growth and survival of juvenile penaeid shrimp. In: DeLoach P, Dougherty WJ, Davidson MA (eds) Frontiers of shrimp research. Elsevier Science Publisher BV, Amsterdam, p 1-16

Mitsch WJ, Wilson RF (1996) Improving the success of wetland creation and restoration with know-how, time, and self-design. Ecol Appl 61:71-83

Mock CR (1967) Natural and altered estuarine habitats of penaeid shrimp. Proc Gulf Caribb Fish Inst 19:86-98

Perez-Farfante I, Kensley BF (1997) Penaeoid and sergestoid shrimps and prawns of the world: keys and diagnoses for the families and genera. Mem Mus Natl Hist Nat 175: $1-233$

Ragotzkie RA, Bryson RA (1955) Hydrography of the Duplin River, Sapelo Island, Georgia. Bull Mar Sci Gulf Caribb 5:297-314 
Rozas LP (1995) Hydroperiod and its influence on nekton use of the salt marsh: a pulsing ecosystem. Estuaries 18:579-590

Rozas LP, Minello TJ (1998) Nekton use of salt marsh, seagrass, and nonvegetated habitats in a south Texas (USA) estuary. Bull Mar Sci 63:481-501

Rozas LP, Odum WE (1987) Use of tidal freshwater marshes by fishes and macrofaunal crustaceans along a marsh stream-order gradient. Estuaries 10:36-43

Rozas LP, Zimmerman RJ (2000) Small scale patterns of nekton use among marsh and adjacent shallow nonvegetated areas of the Galveston Bay Estuary, Texas (USA). Mar Ecol Prog Ser 193:217-239

Ruiz GM, Hines AH, Posey MH (1993) Shallow water as a refuge habitat for fish and crustaceans in non-vegetated estuaries: an example from Chesapeake Bay. Mar Ecol Prog Ser 99:1-16

Rulifson RA (1981) Substrate preference of juvenile penaeid shrimp in estuarine habitats. Contrib Mar Sci 24:35-52

Snedecor GW, Cochran WG (1980) Statistical methods, 7th edn. Iowa State University Press, Ames, IA

Sokal RR, Rohlf FJ (1995) Biometry. The principles and practice of statistics in biological research, 3rd edn. WH Freeman \& Co, New York

South Atlantic Fishery Management Council (1993) Fishery management plan for the shrimp fishery of the South Atlantic region, South Atlantic Fishery Management Council Charleston, SC

Szedlmayer ST, Able KW (1993) Ultrasonic telemetry of age-0 summer flounder, Paralichthys dentatus, movements in a southern New Jersey estuary. Copeia 1993:728-736

Trent L, Pullen EL, Proctor R (1976) Abundance of macro-

Editorial responsibility: Otto Kinne (Editor),

Oldendorf/Luhe, Germany crustaceans in a natural marsh and a marsh altered by dredging, bulkheading, and filling. Fish Bull US 74: $195-200$

Turner RE (1977) Intertidal vegetation and commercial yields of penaeid shrimp. Trans Am Fish Soc 106:411-416

Vance DJ, Haywood MDE, Staples DJ (1990) Use of a mangrove estuary as a nursery area by postlarval and juvenile banana prawns, Penaeus merguiensis de Man, in northern Australia. Estuar Coast Shelf Sci 31:689-701

Vance DJ, Haywood MDE, Heales DS, Staples DJ (1997) Seasonal and annual variation in abundance of postlarval and juvenile grooved tiger prawns Penaeus semisulcatus and environmental variation in the Embley River, Australia: a six year study. Mar Ecol Prog Ser 135:43-55

Wadsworth JR (1980) Geomorphic characteristic of tidal drainage networks in the Duplin River system, Sapelo Island, Georgia. PhD dissertation, University of Georgia, Athens, GA

Webb SR (2000) Growth and movement of juvenile white shrimp, Litopenaeus setiferus, within a tidal marsh landscape. MS thesis, University of Georgia, Athens, GA

Weinstein MP (1979) Shallow marsh habitats as primary nurseries for fishes and shellfish, Cape Fear River, North Carolina. Fish Bull US 77:339-357

Wenner EL, Beatty HR (1993) Utilization of shallow estuarine habitats in South Carolina, USA, by postlarval and juvenile stages of Penaeus spp. (Decapoda: Penaeidae). J Crustac Biol 13:280-295

Zein-Eldin ZP, Renaud ML (1986) Inshore environmental effects on brown shrimp, Penaeus aztecus, and white shrimp, $P$. setiferus, populations in coastal waters, particularly of Texas. Mar Fish Rev 48:9-19

Submitted: June 25, 2001; Accepted: October 16, 2001

Proofs received from author(s): April 8, 2002 